\title{
CITRA SATELIT LANDSAT 8 + TRIS SEBAGAI TINJAUAN AWAL DARI MANIFESTASI PANAS BUMI DI WILAYAH GUNUNG ARGOPURA
}

\author{
M.Singgih Purwanto ${ }^{1)}$, Alif Al Bashri ${ }^{1)}$, Mochammad Fauzan Dwi Harto ${ }^{1)}$, Yuri Syahwirawan ${ }^{1)}$ \\ ${ }^{1}$ Departemen Geofisika ITS, Fakultas Teknik Sipil Dan Perencanaan, ITS Surabaya \\ alif.al.bashri@gmail.com
}

\begin{abstract}
Abstrak. Gunung Argopura merupakan daerah yang berpotensi sebagai sumber daya panas bumi di jawa timur. Dapat dibuktikan dengan adanya manifestasi panas bumi disekitar kawasan gunung argopuro yakni sumber air panas di daerah Tiris berada diantara gunung lemongan dan argopura. Pada makalah ini terdapat analisa manifestasi panas bumi menggunakan pengolahan data - data citra satelit LandSat 8 TRIS. Citra Satelit yang diperoleh berupa kawasan regional gunung argopuro dengan deretan gunung lainnya di jawa timur. Setelah didapatkan data citra tersebut kemudian dilakukan koreksi radiometric dan selanjutnya di komposit band data data spasialnya meliputi band 5, 6, 7 dengan tujuan diperoleh false color. Hasil Interpretasinya berupa adanya manifestasi panas bumi di kawasan regional gunung argopuro meliputi sumber air panas dan fummarol di dekat patahan pada gunung argopuro yang diperoleh dari pengolahan data citra tersebut. Dengan demikian hasil penelitian dapat dimanfaatkan untuk keperluan kajian studi manifestasi panas bumi regional gunung Argopuro.
\end{abstract}

Kata Kunci : Citra Satelit LandSat 8 TRIS, Fummarol, Gunung Argopura

\begin{abstract}
Mount Argopura is a potential region as geothermal resources in eastern Java. It can be proven by a manifested geothermal around the mountain argopura such as hot springs in the Tiris's Region between mount argopuro and lemongan. In this papers is discuss about analysis manifested of geothermal using processing of satellite imaging with LandSat 8 TRIS. The satellite imaging that get from satellite's data is regional data of mountain argopura and the others mountain of eastern java. After that, we use radiometric correction then we use composite band method in band 5, 6, 7 and its purpose to get false colour in spatial data processing. The interpretation result from this paper is manifest of geothermal in the region mount argopura including hot spring and fumaroles that near from fault line of argopura. Thus, this paper can be used to references case study about geothermal manifest in the argopura region.
\end{abstract}

Keyword : Fumarole, LandSat 8TRIS of Satellite Imagenery, Mount Argopura

\section{PENDAHULUAN}

Sumber panasbumi di Jawa Timur telah diketahui kurang lebih ada 11 lokasi sumber panasbumi di Jawa Timur. Empat dari 11 lokasi tersebut (WelirangArjuno, Wilis-Argopuro, tirislamongan dan Blawanljen) diperkirakan mempunyai cadangan yang mungkin sebesar 479 MWe dan sumber daya sebesar 203 Mwe. Salah satu lokasi di Jawa Timur yang berpotensi adalah di Kabupaten Probolinggo. Manifestasi yang tampak berupa sumber air panas di daerah Tiris yang memiliki potensi panasbumi yang berada di antara Gunung Lamongan dan Gunung Argopuro. Sumber panasbumi Tiris memiliki potensi sebesar 147 Mwe dan memiliki suhu permukaan $(40-45)^{\circ} \mathrm{C}$ dengan luas area mencapai $10 \mathrm{~km}^{2}$.

Menurut Herawati (1988: 6-8) Situs Gunung Argopuro keadaan tanahnya berasal dari hasil sedimentasi gunung api kwarter tua, \pm 1 juta tahun yang lalu. Apabila kita mengacu kepada pembagian tipe gunung menurut Newmann (Bronto, 2001: 6). Gunung Argopuro dapat dimasukkan ke dalam gunung aktif tipe $B$ yang kegiatannya terjadi pada masa prasejarah atau sebelum tahun 1600. Penentuan sebagai gunung api berdasarkan bentuk tubuh gunung api, yang umumnya berupa kerucut komposit dan kenampakan kegiatan magma di permukaan bumi. Gunung api Argopuro ini 
merupakan gunung api purba, sehingga kegiatan vulkanologisnya sudah mulai berkurang bahkan dapat dikatakan berstatus istirahat (reses).

Gunung Argopuro yang berada di Pegunungan lyang ini sebenarnya masuk ke dalam pegunungan lainnya yang lebih besar, yaitu Pegunungan Kendeng. Pegunungan ini membujur dari barat ke timur di wilayah Jawa Timur. Rangkaian pegunungan ini bersanding dengan gunung-gunung lainnya seperti: Gunung Semeru, Lawu, Bromo, dan Gunung Raung. Lebih jelasnya dapat dilihat pada peta geologi kawasan Gunung Argopura

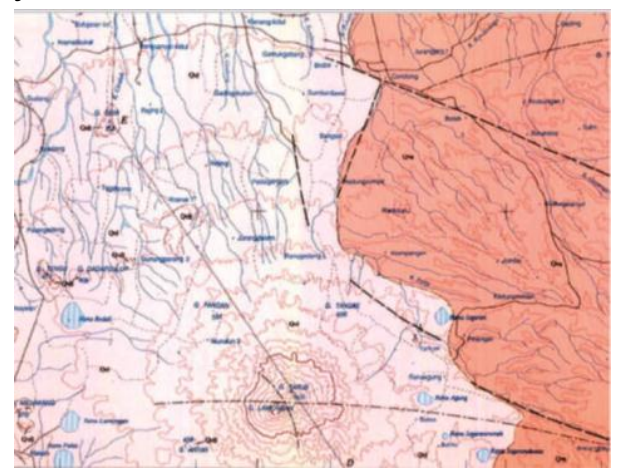

Gambar 1 Peta Geologi Regional Kawasan Gunung Argopura

\section{METODOLOGI}

Pada pendugaan manifestasi panas bumi di kawasan gunung Argopuro menggunakan metode penginderaan jauh. Data yang digunakan berupa citra satelit yang merekam kawasan permukaan bumi dan data yang menjadi acuan dalam pendugaan ini adalah citra satelit LandSat - 8 TRIS. Citra Landsat ini digunakan untuk mengannalisa manifestasi panas bumi yang terlihat pada kawasan gunung Argopura secara regional. Seperti flowchart dibawah ini.

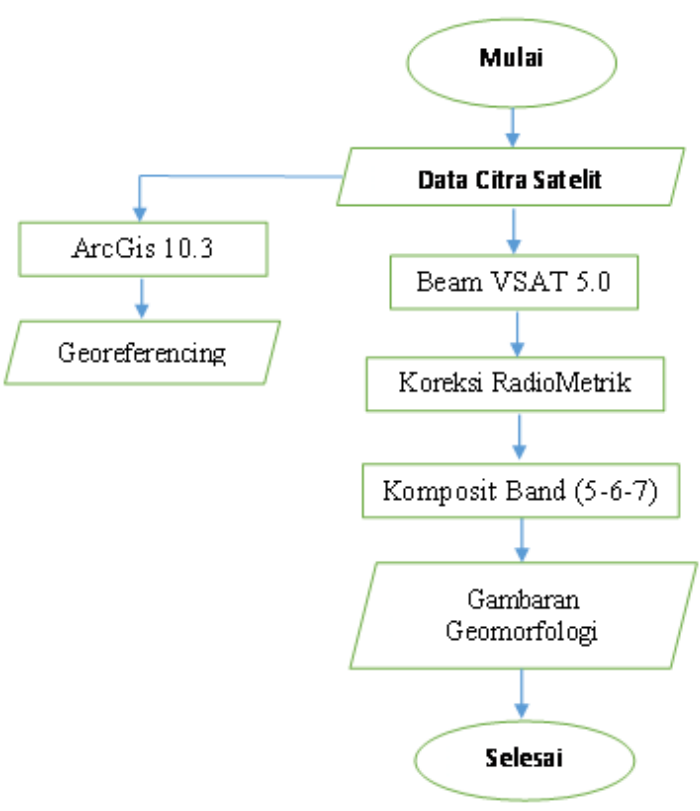

Gambar 2 Diagram Alir Prosseing Data LandSat 8

\section{Data Citra Satelit}

Data Citra Satelit merupakan hasil penginderaan jauh oleh wahana satelit melalui pengukuran energi gelombang elektromagnetik tertentu yang dipancarkan oleh objek di permukaan bumi. Citra satelit Tidak ada kontak fisik secara langsung dengan objek atau fenomena yang dikaji dalam pengukurannya. Respon radiasi dari masingmasing spektrum gelombang elektromagnetik berasosiasi dengan karaktersitik material objek. Respon masing-masing spektrum gelombang elektromagnetik dikumpulkan dalam bentuk rekaman citra multispektral. Data tersebut sebagai acuan informasi dalam segala aspek eksplorasi seperti eksplorasi awal panas bumi. Untuk mendapatkan data tersebut, dapat diperoleh secara gratis di website USGS (United States Geological Survey). 
Adapun aplikasi pengolahan data citra satelit adalah ArcGis 10.3 dan Beam VSAT 5.0 yang digunakan untuk interpretasi data dari citra satelit. Lalu dalam pengolahan data tersebut menggunakan beberapa koreksi diantaranya :

\section{Koreksi RadioMetrik}

Koreksi radiometrik merupakan langkah awal dalam pemrosesan data spasial seperti citra satelit landsat 8 TRIS tersebut dengan prinsip Algoritma. Tujuan utama dari koreksi radiometrik ini adalah untuk mengubah data pada citra yang (pada umumnya) disimpan dalam bentuk digital number (DN) menjadi radian. Nilai spektral radian diperoleh dari file metadata yang berada pada setiap data citra satelit Landsat. Persamaan yang digunakan untuk mengubah dn ke radian (L) adalah sebagai berikut:

Konvesi dn ke ToA (Top of Atmosphere) Radian:

dengan:

$$
\mathrm{L} \lambda=\mathrm{MLQ} c a l+\mathrm{A} L
$$

$\mathrm{L} \lambda=$ ToA spectral radian (Watts $/(\mathrm{m} 2 * \operatorname{srad} * \mu \mathrm{m}))$

$\mathrm{ML}=$ Band-spesifik multiplicative rescaling factor dari metadata

$\mathrm{AL}=$ Band-specific additive rescaling factor dari metadata

\section{Komposit Band}

Komposit warna merupakan perpaduan tiga band yang berbeda dan menghasilkan warna sesuai dengan perpaduan band tersebut. Tiap-tiap band yang dipadukan akan mewakili masing-masing warna dalam format RGB (Red Green Blue). Penggabungan akan menghasilkan gambar true color atau false color (bukan warna sebenarnya). Penelitian ini dilakukan komposit pada band 5-6- 7, untuk mendapatkan gambaran geomorfologi dengan false color.

\section{HASIL DAN PEMBAHASAN}

Data Citra Satelit yang telah diperoleh dari website USGS tersebut kemudian diolah menggunakan aplikasi BeamVSAT 5.0 dengan metode koreksi Radiometrik. Dari data citra satelit yang diperoleh meliputi band 1-11, yang digunakan adalah band 5, 6, dan 7. Hasil Koreksi yang diperoleh seperti gambar dibawah ini.

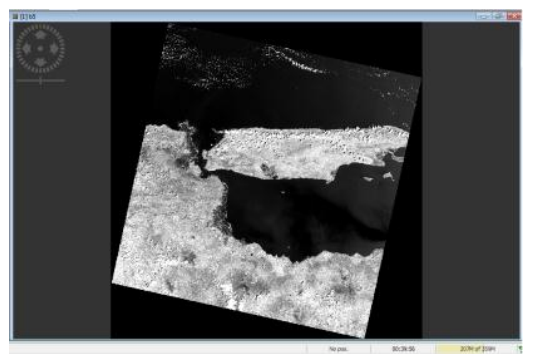

Gambar 3 Hasil Koreksi Radiometrik pada Band 5 Menggunakan BeamVSAT 5.0

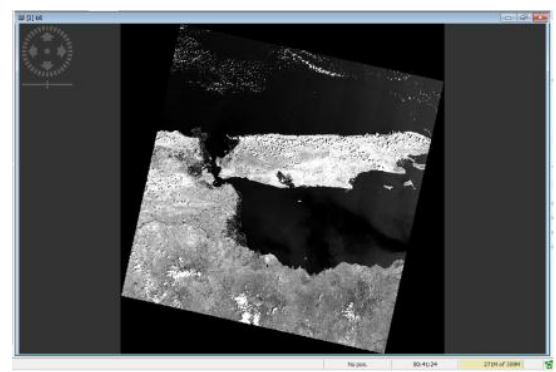

Gambar 4 Hasil Koreksi Radiometrik pada Band 6 Menggunakan BeamVSAT 5.0

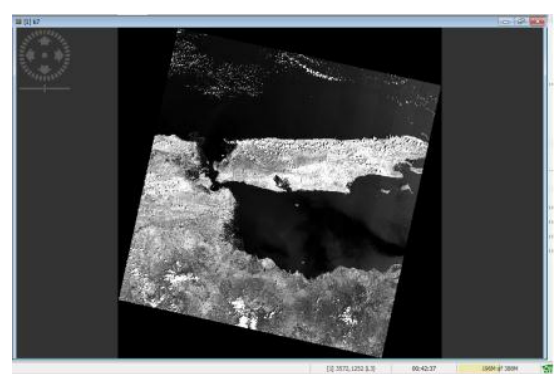

Gambar 5 Hasil Koreksi Radiometrik pada Band 7 Menggunakan BeamVSAT 5.0

Kemudian dari hasil koreksi tersebut dilakukan dekomposit band 5, 6, dan 7 untuk memperoleh false color, tujuannya untuk memperoleh gambaran geomorphology pada kawasan panas bumi di Gunung Argopura dan mempermudah kita dalam menganalisa pendugaan manifestasi panas bumi di kawasan tersebut. Hasil dekomposit band tersebut seperti gambar dibawah ini. 


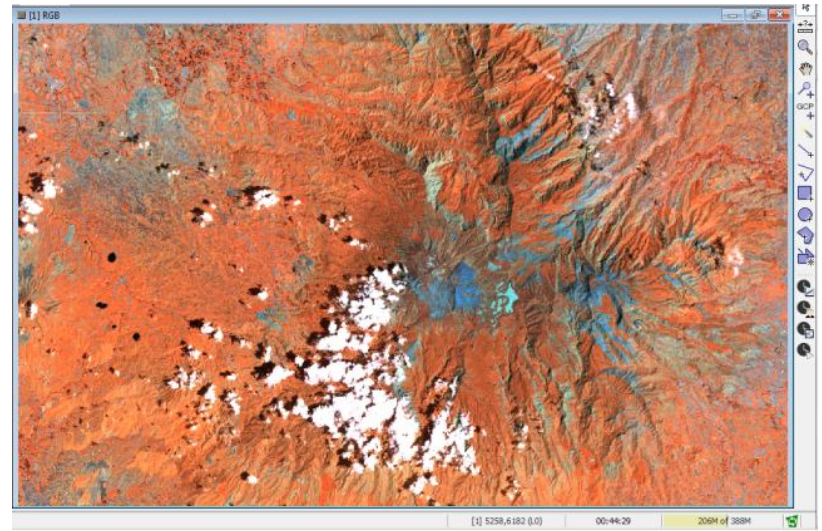

Gambar 6 Hasil Komposit Band 5,6,7

\section{Menggunakan BeamVSAT 5.0}

Pada Gambar 5 dibawah ini menunjukkan bahwa manifestasi panas bumi diasumsikan pada lingkaran biru sebagai fummaroll yang keluar dikawasan dan terdapat sumber mata air panas yang ditunjukkan lingkaran hitam pada kawasan tersebut. Sumber mata air panas tersebut terletak diantara gunung argopuro dan lemongan seperti yang ditunjukkan pada lingkar biru yang paling barat. Kemudian untuk garis garis hitam ini menunjukkan sesar dan patahan pada gunung Argopura. Hal tersebut mengindikasikan bahwa menyebabkan adanya fumarrool yang keluar di dekat patahan pada gunung argopuro tersebut.

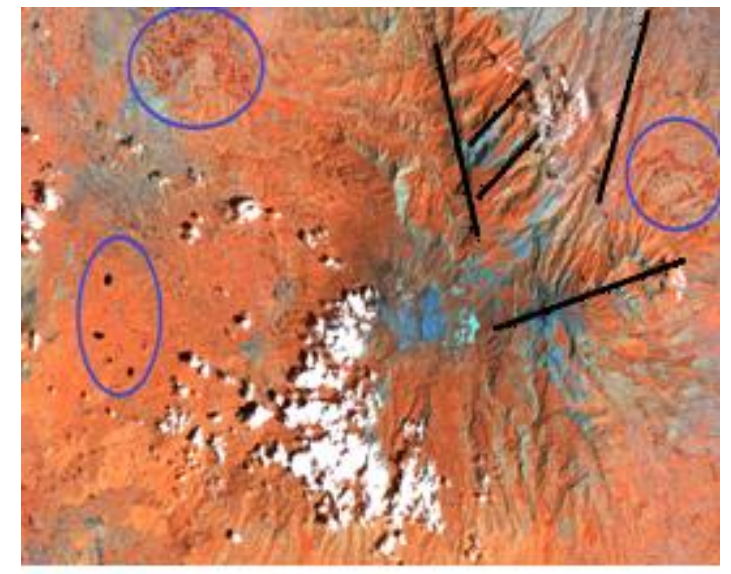

Gambar 7 Hasil Analisa Komposit Band 5,6 dan 7

\section{PENUTUP}

\section{Simpulan}

1. Citra satelit Landsat-8 dapat gunakan untuk keperluan dalam analisa struktur pada wilayah potensi panas bumi dengan melihat pola kelurusannya patahan nya.

2. Citra satelit Landsat- 8 dapat menjadi referensi untuk pendugaan manifestasi panas bumi.

\section{Saran}

Perlu dilakukan korelasi antara data citra satelit, data geologi regional, maupun data aeromagnetic dan gravity agar mendapatkan hasil yang lebih komprehensif.

\section{Daftar Pustaka}

Albab, Ali. 2012. Idenitifikasi Struktur Geologi Menggunakan Integrasi Data Citra Satelite Landsat 8 ETM+ dan SRTM, studi Kasus Jawa Tengah Bagian Utara. Skripsi, Teknik Geologi Universitas Diponegoro, Semarang.

Bronto, S., 2006. Fasies gunungapi dan aplikasinya. Jurnal Geologi Indonesia, Vol. 1 No. 2 Juni 2006: 59-71.

Widya Utama, S. Riski, A.S. Bahri, dan D.D. Warnana (2012), “Analisis Citra Landsat 7 ETM+ untuk Kajian Awal Penentuan Daerah Potensi Panas Bumi di Gunung Lamongan, Tiris, Probolinggo", Jurnal Fisika dan Aplikasinya, Jur. Fisika MIPA, ITS 